\title{
OTORITAS KYAI PENGASUH DI PONDOK PESANTREN AL-FANANI UNIVERSITAS MUHAMMADIYAH JEMBER
}

\author{
Siti Nursyamsiyah \\ Dosen Program Studi Pendidikan Agama Islam Fakultas Agama Islam \\ Universitas Muhammadiyah Jember \\ Email : Sitinursyamsiah@unmuhjember.ac.id
}

\begin{abstract}
Islamic boarding schools as an Islamic educational institution dated back from the history of Islamic ideology, especially in Indonesia, and cannot be separated from specific type of leadership called Kyai. Kyai is usually considered as a source of absolute power and authority in the life and environment of pesantren (i.e., Islamic boarding schools). So all policies both from the purpose up to implementation come from one authority. Kyai controls all sectors of Islamic boarding school. This fact normally leads to the formation of absolute authority by Kyai. Tahfidzul Qur'an Al-Fanani Islamic Boarding School, based on the results of a preliminary study, provides a different portrait in comparison with other Islamic boarding schools. Tahfidzul Qur'an Al-Fanani Islamic Boarding School, which was founded by Universitas Muhammadiyah Jember, becomes an interesting phenomenon to study. The questions of this study were formulated as follows: 1. What form of authority is applied in the Tahfidzul Qur'an AlFanani boarding school? 2. What factors support and inhibit leadership in Tahfidzul Qur'an Al-Fanani Islamic boarding school? 3. How does leadership authority affect the existence of 'santri' in the Tahfidzul Qur'an Al-Fanani boarding school? This study aimed to find a comprehensive picture of the leadership model in Al-Fanani boarding school. This study employed a qualitative approach involving interviews and documentation. Data analysis technique was triangulation. The findings show that, first, the form of authority is traditional. Second, the supporting factor is rote learning becomes the authority of each teacher (ustadz), not the leader. Meanwhile, the inhibiting factor lies in the difference between the status of 'santri' from ordinary students. Finally, third, Kyai affected the number of santri, which does not increase every year.
\end{abstract}

Kata kunci : Otoritas, Pesantren, Pengasuh

\section{PENDAHULUAN}

Pondok pesantren adalah suatu tempat pendidikan dan pengajaran yang menekankan pelajaran agama Islam dan didukung asrama sebagai tempat tinggal santri yang bersifat permanen. Selain itu, pondok pesantren merupakan salah satu lembaga pendidikan non formal yang tersebar di Indonesia. Di mana pondok pesantren lahir ditengah-tengah masyarakat. Kedudukan pondok pesantren dalam system pendidikan di Indonesia diatur di dalam UU sisdiknas No. 20 Tahun 2003 tentang pendidikan keagamaan pasal 30, bahwa pondok 
pesantren merupakan salah satu bentuk dari pendidikan keagamaan yang diselenggarakan oleh pemerintah dan atau kelompok masyarakat dari pemeluk agama, sesuai dengan peraturan perundang-undangan (ayat 1), serta dapat diselenggarakan lewat jalur formal, nonformal, dan informal (ayat 3) (Kresnawan, 2010:20).

Setiap pondok pesantren memiliki ciri khas yang berbeda-beda tergantung dari bagaimana tipe reader shipnya dan metode seperti apa yang diterapkan dalam pembelajarannya. Kehidupan di pesantren sangat dikenal dengan kepatuhan dan kemandirian santrinya. Kepatuhan terhadap kyai dan kemandirian menjadi dua aspek psikologis yang sangat lekat dengan kehidupan santri di pesantren. Kepatuhan adalah perubahan sikap dan tingkah laku seseorang untuk mengikuti permintaan atau perintah orang lain (Hartono, 2006:1).

Pondok pesantren adalah lembaga pendidikan Islam asli Indonesia dan memiliki akar sangat kuat dalam kehidupan masyarakat. Ditilik dari sejarah pendidikan Islam Indonesia, pesantren mempunyai peranan yang signifikan dalam proses pencerdasan bangsa. Sebagai bagian yang tidak terpisahkan dari sejarah pendidikan nasional, pesantren telah berjasa dalam mengembangkan pengetahuan keislaman, membentuk moral bangsa dan mencetak kader elit strategis bangsa. Sebagai lembaga tafaqquh fiddin, pesantren memiliki fungsi memelihara, mengembangkan, menyiarkan dan melestarikan agama Islam dan sudah barang tentu juga ingin mencetak santri atau tenaga-tenaga pengembang ilmu agama. Sebagaimana yang diungkapkan oleh Mastuhu, pesantren dibentuk untuk memahami, mempelajari dan mengamalkan ajaran agama Islam dengan menekankan pentingnya moral agama Islam sebagai pedoman hidup sehari-hari
(Mastuhu, 1994:6). Model pendidikan yang diselenggarakan pesantren secara legal diakui oleh semangat UndangUndang RI No.20 tahun 2003 tentang sistem pendidikan Nasional.

Kajian mengenai pesantren sangat potensial untuk dieksploitasi, baik secara politis, ekonomis, dan discourse (wacana) karena realitas pesantren sekarang yang begitu banyak belum tentu mampu membendung arus zaman yang terus berkembang. Kondisi semacam ini, memaksa mereka untuk membenahi diri bagaimana menjaga eksistensi terhadap masyarakat pragmatis dan materialis dalam gejolak modernisasi. Pesantren merasa memiliki beban dan tanggung jawab bagaimana untuk membangkitkan kembali etos pesantren guna menggapai format pesantren ideal di zaman modern.

Stigma buruk akan manajemen pondok pesantren (ponpes) di negeri ini nampaknya belum lenyap betul. Jeleknya manajemen ponpes menyebabkan institusi pendidikan nonformal ini dianggap sebagai lembaga pendidikan yang tetap melanggengkan status qua-nya sebagai institusi pendidikan yang tradisional, konservatif, dan terbelakang. Anehnya institusi pendidikan ini tetap diminati masyarakat dan tetap eksis dari tahun ke tahun. Namun demikian tidak sedikit di antara ponpes yang ada, yang dulu memiliki banyak santri kemudian menjadi tidak berpenghuni. Hingga belakangan muncul ponpes tanpa santri.

Pesantren sekarang ini sudah banyak mengalami perubahan dan perkembangan dan tidak membiarkan dirinya dalam ketradisionalan yang berkepanjangan, tetapi lebih pada adaptasi dan adopsi nilai-nilai baru, baik secara langsung maupun tidak langsung. Namun, perubahan dan perkembangan pesantren tidak lepas dari pemimpin pesantren yaitu kyai yang merupakan pemegang prinsip manajemen, pengatur perkembangan dan kelangsungan kehidupan pesantren 
dengan keahlian, kedalaman ilmunya, kharismatik dan keterampilannya, Begitu juga Bawani (1993: 90) mengatakan kyailah perintis, pendiri, pemimpin dan pengelola sebuah pesantren. Karena itulah segala sesuatu terletak pada kebijaksanaan dan keputusan dari kyai.

Pemimpin atau pengasuh selain menjadi perumus visi, misi dan sasaran pesantren, pemimpin juga berperan dalam menentukan strategi pencapaiannya dan mengarahkan stakeholder kepada pencapaian tujuan tidak terkecuali dalam hal pengelolaan pengetahuan. Kepemimpinan pada dasarnya adalah kemampuan seseorang untuk mempengaruhi dan memotivasi bawahannya agar mau memberikan kontribusi pada pencapaiaan tujuan organisasi (McShane, 2008: 86). Dari pengertian ini jelas tergambar bahwa perilaku seluruh anggota organisasi serta tercapainya tujuan sangat ditentukan oleh kemampuan seorang pemimpin.

Kepemimpinan tidak bisa dilepaskan dari kemampuan, kewibawaan dan kekuasaan. Yang dimaksud dengan kemampuan adalah segenap daya, kesanggupan, kekayaan, kecakapan dan kekuatan yang terdapat pada individu untuk bertingkah laku, khususnya sebagai pemimpin. Sedangkan kewibawaan adalah pemimpin yang memiliki kewibawaan itu mempunyai kelebihan, sehingga dia kuasa membawa orang lain untuk melakukan perbuatan-perbuatan tertentu, atau dia mampu memberikan pengaruh-pengaruh kepemimpinannya kepada bawahan atau pengikutnya. Karena itu kewibawaan merupakan kebutuhan atau keperluan teknis, karena akan menimbulkan kepatuhan normative pada para perilaku dan yang dimaksud dengan kekuasaan adalah kekuatan, otoritas, pengaruh untuk mengatur dan mengarahkan pengikutnya.

Posisi kyai pengasuh yang serba menentukan dalam sistem pembelajaran dan kehidupan santri akhirnya justru cenderung menyebabkan terbangunnya otoritas mutlak. Zamkhsari Dhofir dalam bukunya yang berjudul Tradisi Pesantren Studi tentang Pandangan Hidup Kyai, mensinyalir bahwa kebanyakan kyai di Jawa beranggapan bahwa suatu pesantren dapat diibaratkan kerajaan kecil dimana kyai merupan sumber mutlak dari kekuasaan dan kewenangan (power and authority) dalam kehidupan dan lingkungan pesantren. Sehingga seluruh kebijakan pesantren baik dari tujuan, pelaksanaan, maupun evaluasinya menjadi otoritas kyai pengasuh. Kyai menguasai dan mengendalikan seluruh sektor kehidupan pesantren. Ustadz apalagi santri, baru berani melakukan sesuatu tindakan di luar kebiasaan setelah mendapat restu dari kyai.

Kearifan lokal dalam proses berdirinya pesantren tentu memiliki domain tersendiri. Sehingga dapat dimungkinkan antara satu pesantren dengan pesantren lainnya berbeda baik dalam pola pengasuhan, ortorita dan kepemimpinannya.

Pesantren Al-Fanani merupakan fakta yang mewakili realitas tersebut. Pesantren Al-Fanani yang didirkan oleh Universitas Muhammadiyah Jember memiliki karaterisk, ciri dan corak tersendiri sehingga menjadi sebuah fenomena yang menarik untuk diteliti. Deskripsi tersebut menghasilkan rumusan : 1. Bagiamana bentuk otoritas yang diterapkan di Pesantren Tahfidzul Qur'an Al-Fanani Universitas Muhammadiyah Jember?; 2. Faktor apa saja yang menjadi pendukung dan penghambat otoritas pimpinan pesantren Tahfidzul Qur'an AlFanani Universitas Muhammadiyah Jember?; dan 3. Bagiaman dampak otoritas pimpinan terhadap keberadaan santri di pesantren Tahfidzul Qur'an AlFanani Universitas Muhammadiyah Jember?.

Penelitian ini bertujuan mengungkapkan pola asuh, identifikasi 
faktor-faktor pendukung dan penghambat dan menguraikan dampak perbedaan pola asuh terhadap keberadaan santri di pesantren Tahfidzul Qur'an Universitas Muhammadiyah Jember.

\section{METODE PENELITIAN}

Penelitian ini bertujuan untuk mendeskripsikan otoritas kyai pengasuh di pondok pesantren tahfidzul Qur'an dalam sistem pembelajaran. Pendekatan yang dilakukan dalam penelitian ini adalah pendekatan kualitatif karena (1) peneliti bertindak sebagai instrumen utama, karena disamping sebagai pengumpul data dan penganalisis data, peneliti juga terlibat langsung dalam proses penelitian, (2) mempunyai latar alami (natural setting), data yang diteliti dan dihasilkan akan dipaparkan sesuai dengan yang terjadi di lapangan, (3) hasil penelitian bersifat deskriptif, karena data yang dikumpulkan bukan berupa angka-angka melainkan berupa kata-kata dan kalimat, (4) lebih mementingkan proses dari pada hasil, (5) adanya batas masalah yang ditemukan dalam fokus penelitian, dan (6) analisis data cenderung bersifat induktif. Hal ini sesuai dengan pendapat Moleong (2002:48).

Penelitian ini memakai rancangan kualitatif. Penelitian kualitatif memiliki beberapa karakteristik, di antaranya berlatar alamiah, deskriptif dan manusia sebagai alat (instrumen). Penelitian kualitatif memiliki karakteristik berlatar alamiah maksudnya di dalam penelitian kualitatif, peneliti memasuki, berhadapan langsung dengan objek penelitian dan hasil penelitiannya adalah alamiah, sesuai dengan keadaan yang sebenarnya tanpa rekayasa. Dalam penelitian ini, peneliti berhadapan langsung dengan objek penelitian, yaitu Kyai pengasuh sebanyak 2 orang dan santri sebanyak 6 orang, kemudian melihat dengan seksama serta mengamati masalah yang diteliti yaitu terkait otoritas kyai pengasuh dalam system pembelajaran di pondok pesantren tahfidzul Qur'an. Dari kajian tersebut memperhatikan dampak otoritas kyai pengasuh dalam system pembelajaran di Pondok Pesantren Universitas Muhammadiyah Jember.

Hasil penelitian ini merupakan data asli, alamiah, sesuai dengan keadaan yang sebenarnya, sesuai dengan data yang ada di pondok pesantren. Pendekatan kualitatif dalam penelitian ini merupakan prosedur penelitian yang menghasilkan data deskriptif yang berupa uraian dan gambaran yang jelas bagaimanan otoritas kyai pengasuh dalam system pembelajaran di Pondok Pesantren Tahfidzul Qur'an AlFanani Universitas Muhammadiyah Kabupaten Jember.

Penelitian kualitatif memiliki karakteristik deskriptif maksudnya, dalam penelitian kualitatif, data yang dikumpulkan berupa kata-kata, gambar, dan bukan angka-angka. Laporan penelitian akan berisi pola-pola komunikasi untuk memberi gambaran penyajian laporan tersebut. Data tersebut berasal dari naskah wawancara, catatan lapangan, foto, dokumen pribadi, catatan atau memo dan dokumen penting lainnya. Data yang dikumpulkan dalam penelitian ini berisi uraian tentang otoritas kyai pengasuh dalam system pembelajaran di Pondok Pesantren Tahfidzul Qur'an AlFanani Universitas Muhammadiyah Kabupaten Jember.

Penelitian ini akan dilaksanakan pada Pondok Pesantren Tahfidz Al-Qur'an Universitas Muhammadiyah Kabupaten Jember. Lokasi ini dipilih sebagai tempat penelitian dengan pertimbangan sebagai berikut:

a. Pondok Pesantren Tahfidz Al-Qur'an merupakan salah satu sarana yang dimiliki oleh Universitas Muhammadiyah Jember sebagai harapan bangsa dan masyarakat mampu mencetak generasi yang 
berkarakter Islami dan penghafal AlQur'an.

b. Pondok Pesantren Tahfidz Al-Qur'an merupakan salah satu sarana yang dimiliki oleh Universitas Muhammadiyah Jember, yang dipegang oleh dua pengasuh yang sangat mumpuni dalam bidang tahfidz Al-Qur'an.

c. Pondok Pesantren tahfidz Al-Qur'an Universitas Muhammadiyah Jember merupakan pondok pesantren mudah dijangkau oleh masyarakat semua kalangan dari segi pembiayaan dan lokasi yang strategis yang berada di dalam lingkungan Universitas.

d. Universitas Muhammadiyah Jember merupakan salah satu lembaga pendidikan Tinggi yang memberikan fasilitas dan layanan pendidikan cukup memadai yang bernafaskan Al Islam dan Kemuhammadiyahan.

\section{HASIL PENELITIAN DAN PEMBAHASAN}

\section{Bentuk Otoritas di Pondok Pesantren Tahfidzul Qur'an Al-Fanani Universitas Muhammadiyah Jember}

Sebelum membahas lebih jauh bentuk otoritas di pesantren Al-Fanani, perlu diketahui apa yang dimaksud kyai, kyai pengasuh dan otoritas, karena kedua kata ini saling berkaitan. Kyai merupakan salah satu faktor yang sangat penting dalam pesantren, bahkan kyai seringkali dikaitkan dengan pendiri pesantren. Katakata kyai bukan berasal dari bahasa Arab melainkan dari bahasa Jawa (Ziemek, 1986: 39). Kata-kata kyai merupakan makna yang agung, keramat, dan dituahkan. Untuk benda-benda yang dikeramatkan dan dituahkan di Jawa seperti keris, tombak, dan benda lain yang keramat disebut kyai (Moebirman, 1970:39). Selain untuk benda, gelar kyai juga diberikan kepada laki-laki yang lanjut usia, arif dan dihormati dijawa (Ziemek, 1986). Bahkan Dhofier (1984:55) juga menjelaskan asal usul perkataan kyai dalam bahasa Jawa dipakai untuk tiga jenis gelar yang saling berbeda, yaitu: 1) sebagai gelar kehormatan bagi barang-barang yang dianggap keramat, 2) gelar kehormatan untuk orang-orang tua pada umumnya, dan 3) gelar yang diberikan oleh masyarakat kepada seorang ahli agama Islam yang memiliki atau menjadi pimpinan pesantren dan mengajar kitab-kitab Islam klasik kepada para santrinya. Selain gelar kyai ia juga sering disebut seorang alim (orang yang dalam pengetahuan islamnya).

Dalam konteks pendidikan Islam, pendidik disebut dengan murabbi, muallim dan muaddib, sedangkan pengasuh tergolong kepada kata murabbi. Kata murabbi berasal dari kata rabba, yurabbi (Ramyulis, 2002: 56). Kata atau istilah "murabbi" sering dijumpai dalam kalimat yang orientasinya lebih mengarah kepada pemeliharaan, baik jasmani atau rohani, pemeliharaan seperti ini terlihat dalam proses orang tua membesarkan anaknya, sedangkan dilembaga pendidikan pesantren dapat pula kita lihat guru atau pengasuh pondok dalam membina akhlak para santrinya (2002: $60)$.

Pengasuh pondok pesantren harus memiliki standar kualitas pribadi tertentu, yang mencakup tanggung jawab, wibawa, mandiri dan disiplin (Jamarah, 2002, 34). Pengasuh pondok pesantren harus mampu mengambil keputusan secara mandiri, terutama dalam berbagai hal yang berkaitan dengan pembelajaran dan pembentukan akhlak dan mental, serta bertindak sesuai dengan kondisi dan lingkungannya.

Penulis menyimpulkan bahwa pengasuh pondok pesantren adalah tenaga pendidik di pondok pesantren yang bertanggung jawab mencerdaskan kehidupan santrinya dan ia memiliki 
pribadi yang bertanggung jawab, berwibawa, mandiri dan disiplin. Penulis juga menjelaskan bahwa pengasuh pesantren yang terdapat dalam penelitian ini hanya seorang pengurus pondok pesantren. Karena yang ikut dalam mengatasi gangguan kejiwaan tidak hanya seorang kyai melainkan pengurus juga ikut serta dalam strategi yang dilakukan. Jadi, pengasuh pesantren merupakan orang yang bertanggung jawab dalam segala kegiatan dilingkungan pesantren. Yang mana di Pesantren Tahfidz AlQur'an Al-Fanani ini orang yang bertanggung jawab dalam pelaksanaan strateginya adalah pengurus Pondok.

Sedangkan otoritas menurut Bernard (dalam Luthans, 1989: 429-430) mendefinisikan otoritas (authority) sebagai "the character of a communication (order) in a formal organization by virtue of which it is accepted by a contributor to or member of the organization as governing the action he contributes. Dalam hal ini Yukl (2001:173) memberikan penjelasan bahwa otoritas melibatkan hak, preogratif, kewajiban, dan tugas yang berkaitan dengan posisi khusus dalam organisasi atau system social. Hoy dan Miskel (2005: 204) mengemukakan hubungan otoritas dalam sekolah memiliki tiga karakteristik, yaitu: (a) a willingness of subordinate to comply; (b) a suspension of the subordinate criteria for making a decision prior to a directive; and (3) a power relationship legitimized by the norm of group. Berdasarkan definisi di atas, otoritas dapat berjalan ketika ada kepercayaan (norma) dalam suatu legitimasi sekolah dengan menggunakan kekuasaan yang benar dan tepat.

Organisasi diciptakan dan dikontrol oleh otoritas yang sah, yang menetapkan tujuan, merancang struktur, mempekerjakan dan mengelola karyawan, dan memantau aktivitas intuk memastikan agar perilaku sejalan dengan tujuan dan sasaran organisasi. Otoritas resmi ini mengontrol atau memegang kekuasaan kantor atau jabatan yang sah, namun otoritas resmi hanyalah salah satu dari banyak pemegang bentuk-bentuk lain kekuasaan dalam organisasi (Bolman dan Deal, 2008).

Otoritas yang baik dan benar yaitu, jika segala sesuatu berjalan dengan baik, di dalam sebuah system pemerintahan, pekerjaan atau bahkan lingkup pelayanan. Otoritas bermanfaat untuk membuat semua berada di dalam lingkup kerja yang dinamis. Semua orang tunduk dan taat serta tidak bisa bersikap semau-maunya sendiri. Aturan yang ditegakkan menjadi acuan bersama. Pemimpin yang mengendalikan situasi, menggunakan otoritas dengan bertanggung-jawab dan tidak menempatkan dirisebagai alat kekuasaan untuk mempengaruhi orang lain. Otoritas digunakan untuk membuat semua system bekerja dengan baik dan mencapai tujuan sebagaimana ditetapkan bersama.

Kriteria otoritas di sekolah sangat penting dalam hubungan atasan-bawahan: (1) kepatuhan sukarela pada perintah yang sah; dan (2) penangguhan kriteria kita sendiri untuk mengambil keputusan dan menerima perintah organisasi. Ketiga kriteria di atas, perlu ditambahkan untuk membedakan otoritas dengan bentukbentuk lain control social. Menurut Peter Blau dan W. Richard cott $(1962,2003)$ berkeyakinan bahwa orientasi nilai pun muncul yang menentukan penggunaan control social sebagi yang sah, dan orientasi nilai hanya muncul di dalam konteks kelompok. Otoritas disahkan oleh sebuah nilai yang dianut bersama oleh kelompok (Surachman, 1995). Blau dan Scott berkesimpulan bahwa karakter dasar hubungan otoritas adalah kesediaanbawahan untuk menangguhkan kriteria pengambilan keputusan sendiri dan tunduk pada perintah dari atasan. Tekanan social semacam ini tidak menjadi 
ciri khas kekuasaan yang koersif dan bentuk-bentuk lain pengaruh social. Dengan demikian, hubungan otoritas di sekolah memiliki tiga karakteristik utama: (1) kesediaan bawahan untuk patuh; (2) penangguhan kriteria pengambilan keputusan bawahan demi mematuhi perintah; dan (3) relasi kekuasaan diabsahkan oleh norma kelompok.

Dalam teori kontinum yang merupakan hasil hasil pemikiran Robert Tannenbaum dan Warren H. Schmidt mengungkapkan 7 (tujuh) tingkatan hubungan pemimpin dengan bawahan, diantaranya:

1. Telling, yaitu pemimpin membuat dan mengumumkan keputusan terhadap bawahan.
2. Selling, yaitu pemimpin menjual dan menawarkan keputusan terhadap bawahan.

3. Pemimpin menyampaikan ide dan pertanyaan.

4. Pemimpin memberikan keputusan tentative, dan keputusan masih dapat diubah.

5. Consulting, yaitu pemimpin memberikan problem dan minta saran pemecahannya kepada bawahan.

6. Pemimpin menentukan batasanbatasan dan minta kelompok untuk membuat keputusan.

7. Joining, yaitu kepemimpinan mengizinkan bawahan berfungsi dalam batas-batas yang ditentukan.

Berdasarkan uraian di atas, teori kontinum dapat digambarkan sebagai berikut:

Gambar 1:

Perilaku Kepemimpinan Berdasarkan Teori Kontinum

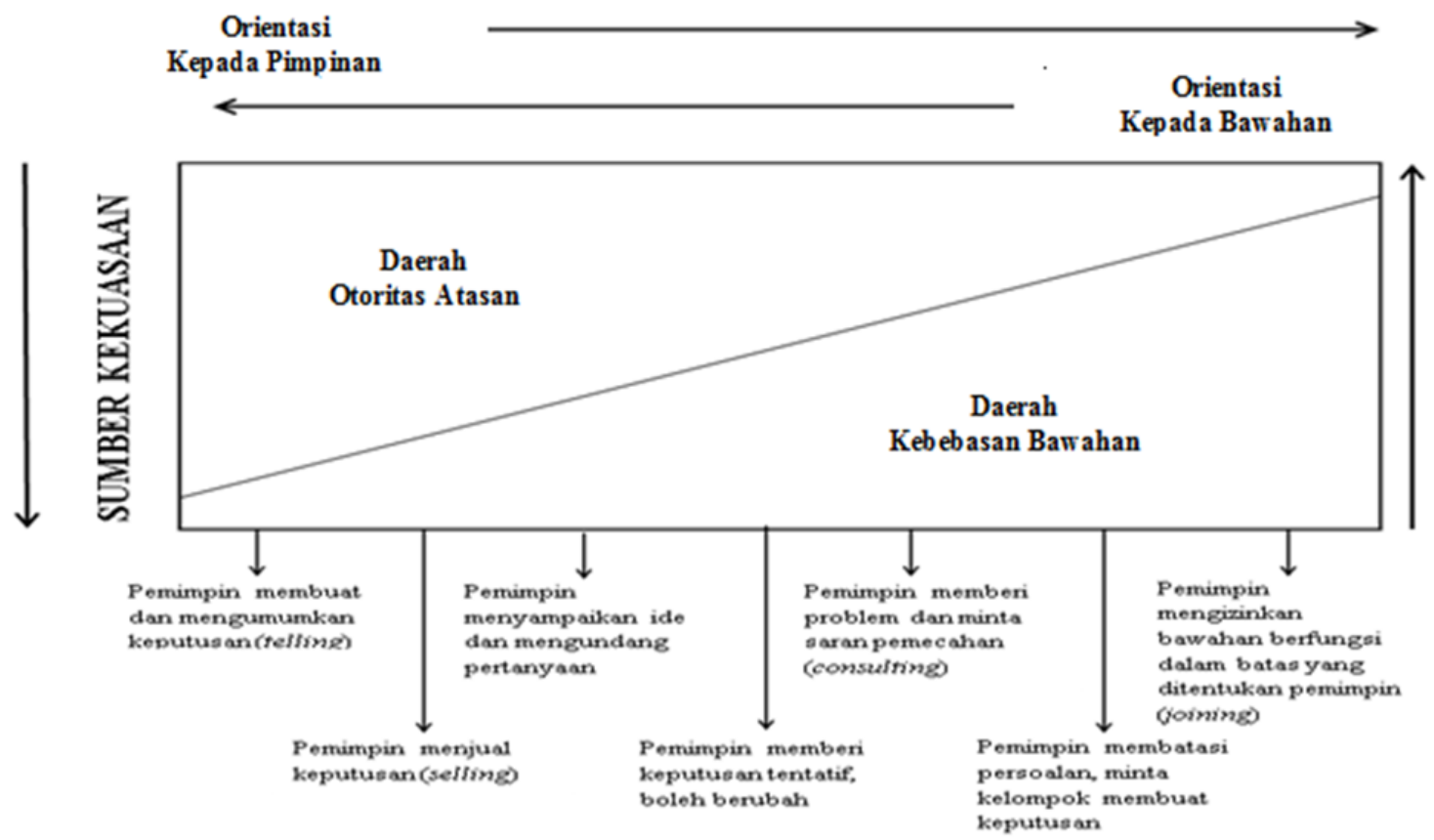

Sumber: Wahjosumidjo, dalam kepemimpinan dan motivasi (1993:65)

Model atau gambar di atas, dapat a) Makin bergeser kekanan, makin dijelaskan sebagai berikut: meluas kebebasan bawahan, sehingga makin nyata bawahan dilibatkan 
dalam proses pengambian keputusan. Dan sebaliknya makin sempit otoritas pemimpin. Jadi, perilaku pemimpin berorientasi kepada bawahan atau disebut kepemimpinan yang bergaya demokratis.

b) Makin bergeser ke kiri, makin meluas otoritas pemimpin. Sehingga makin dibatasi kebebsan bawahan di dalam keterlibatan pengambilan keputusan. Jadi, perilaku pemimpin berorientasi kepada pemimpin atau dapat disebut pula kepemimpinan yang bergaya otoriter.

Jadi, berdasarkan uraian di atas, perilaku pemimpin tidak dapat dipisahkan dengan sifat-sifat pribadi yang dimiliki oleh pemimpin itu sendiri. Bahkan boleh dikatakan, bahwa setiap perilaku yang ditampilkan oleh setiappemimpin pada dasarnya bersumber atau dijiwai oleh nilai-nilai yang tercermin dari sifat-sifat pribadi pemimpin. Dengan demikian ada kaitan yang sangat saling menentukan antara sifat-sifat pribadi sebagai persyaratan dasar seorang pemimpin dengan perilaku pemimpin. Seperti yang diungkapkan oleh Wahjosumidjo (1987:44) bahwa "keberhasilan seorang pemimpin ditentukan oleh sifat-sifat, perangai atau ciri yang dimiliki oleh pemimpin itu". Sifat-sifat tersebut dapat berupa sifat fisik, dan dapat pula sifat psikologis. Oleh karena itu, atas dasar pemikiran tersebut timbul anggapan bahwa untuk menjadi seorang pemimpin yang berhasil, sangat ditentukan oleh kemampuan pribadi si pemimpin. Dan kemampuan pribadi yang dimaksud ialah kualitas seseorang dengan berbagai macam sifat-sifat, perangai atau ciri-ciri di dalam diri si pemimpin.

Berdasarkan asumsi di atas, keberhasilan kepemimpinan kyai di pondok pesantren tidak lepas dari ciri-ciri yang dimilikinya dalam memimpin, mengelola serta dalam mengembangkan pesantren. Karena setiap kyai mempunyai ciri-ciri tertentu dalam memimpin, sehingga keberhasilan seorang kyai ditentukan dari pola dan gaya kepemimpinan yang dugunakannya.

Tingkat otoritas manajerial tertinggi di puncak menurun sampai ke bawah dalam organisasi. Garis otoritas ini dekenal sebagai rantai komando (chain of command). Rantai komando ada jika seseorang menjadi bawahan dan yang lain. Rantai monsep komando, sebagaimana ditunjukkan oleh Buford, Jr. \& Bedelan (1988: 67), sangat terkait dengan dua prinsip manajemen popular yang lain yakni prinsip scalar dan prinsip kesatuan komando.

a. Prinsip skalar menyatakan bahwa garis otoritas yang tegas dan manjer puncak ke masing-masing jabatan bawahan mempengaruhi komunikasi dan pengambilan keputusan.

b. Prinsip kesatuan komando menyatakan bahwa untuk meminimalisasi konflik dan memaksimalisasi tanggungjawab terhadap hasil seseorang harus melapor kepada atasan tunggal.

Pondok pesantren Tahfidzul Qur'an Al-Fanani Universitas Muhammadiyah Jember dipimpin oleh 3 (tiga) orang pengasuh yang mempunyai jabatan masing-masing. Pada hakekatnya setiap manusia adalah pemimpin, paling tidak ia sebagai pemimpin dirinya sendiri. Setiap kyai pengasuh pasti memiliki gaya tersendiri dalam mengelola pesantren tersebut, karena kyai memiliki otoritas masing-masing dalam mengelola, menggerakkan, mengontrol dan mengendalikan seluruh elemen di dalam pesantren. Seperti halnya diungkapkan oleh Hoy dan Miskel (2005:204) mengemukakan hubungan otoritas dalam sekolah memiliki tiga karakteristik, yaitu: (a) a willingness of subordinate to comply; (b) a suspension of the subordinate criteria for making a decision prior to a directive; and (3) a power 
relationship legitimized by the norm of group. Berdasarkan definisi di atas, otoritas dapat berjalan ketika ada kepercayaan (norma) dalam suatu legitimasi sekolah dengan menggunakan kekuasaan yang benar dan tepat.

Sosok kyai pengasuh yang dominan bisa menjadi pemimpin lembaga atau elit dominan mungkin mengatur. Dalam hal ini sesuai dengan teorinya weber (1947:28) mengatakan: otoritas sah merupakan pemberian wewenang atau otoritas yang bersumber dari hukum atau didasarkan pada undang-undang yang telah disahkan yang bisa diubah oleh prosedur-prosedur yang benar secara formal.

Ungkapan di atas selaras apa yang dikatakan Weber (1947:29) mengatakan Otoritas Trdisional, berakar dalam kepercayaan yang kukuh pada kesakralan status orang-orang yang memegang otoritas pada masa lalu. Kepatuhan diberikan kepada posisi otoritas sah tradisional, dan orang yang memegang posisi tersebut mewarisi otoritas yang dibangun oleh jabatan dan mematuhi guru karena orang tua dan neneknya melakukan tindakan tersebut sebelumnya.

Kedudukan kyai pengasuh pesantren yang tidak sama ini berdampak pada otoritas yang dimilikinya, ini bisa dilihat dari faktor dalam memutuskan kebijakan dan peraturan yang ada di pondok pesantren Al-Fanani Universitas Muhammadiyah Jember terkadang cenderung menggunakan otoritas tradisional.

Dari pernyataan di atas, otoritas yang benar dan baik yaitu, segala sesuatu berjalan dengan baik, di dalam sebuah system pemerintahan, pekerjaan atau bahkan lingkup pelayanan. Otoritas bisa bermanfaat untuk membuat semua yang berada dalam lingkup kerja yang dinamis. Otoritas digunakan untuk membuat sisem bekerja dengan baik dan mencapai tujuan sebagaimana ditetapkan bersama.
Dengan demikian dapat disimpulkan bahwa, baik buruknya otoritas di pesantren Al-Fanani, serta akibat yang ditimbulkannya, tidak ditentukan oleh otoritas itu, melainkan oleh orang yang mendapatkan atau menggunakan otoritas tersebut. Jika seorang pemimpin memiliki pengaruh yang kuat, orang-rang yang berada dalam lembaga pesantren pengaruhnya, sebetulnya telah memberikan otoritas kepada pemimpin itu dengan sendirinya.

Uraian di atas dapat disimpulkan bahwa otoritas itu berhubungan dengan kekuasaan yang dimiliki seseorang atau sekelompok orang yang memiliki hak, wewenang dan legitimasi untuk mengatur, memerintah, memutuskan sesuatu, menegakkan aturan serta otoritas memiliki kaitan yang sangat erat dengan kekuasaan yang dimiliki seseorang. Semakin tinggi kekuasaan yang dimiliki dalam lembaga pesantren, maka otoritas yang dimilikinya semakin kuat.

\section{Faktor-Faktor yang Mendukung dan Menghambat Otoritas Kyai Pengasuh Pesantren Tahfidzul Qur'an Al-Fanani Universitas Muhammadiyah Jember}

Kepemimpinan kyai pengasuh sangat berpengaruh terhadap keberhasilan sebuah organisasi dalam mencapai tujuannya. Kyai pengasuh sebagai pengontrol juga bertindak sebagai pembangun motivasi bawahan serta penyusunan system kerja dan pengembagan kualitas organisasi dan orang-orang yang tergabung dalam organisasi tersebut. Seorang Kyai pengasuh haruslah memiliki otoritas dalam penyelenggaraan tugas dan tanggung jawabnya. Otoritas inilah yang akan mendorongnya untuk membuat kebijakan dalam pelaksanaan tugas kepemimpinannya.

Adapun faktor yang mendukung otoritas kyai pengasuh berdasarkan pada beberapa indicator, di antaranya: 
1. Faktor kemampuan personal

Kyai pengasuh mempunyai kemampuan dalam memimpin pesantren dalam artian mampu mengendalikan, mengarahkan semua elemn yang ada di pesantren Tahfidzul Qur'an Al-Fanani Universitas Muhammadiyah Jember. Kemampuan personal tersebut sejak pemimpin dilahirkan atau melalui pendidikan edukatif.

2. Faktor Jabatan

Kyai pengasuh merupakan jabatan yang harus dihargai, Jabatan kyai pengasuh di pondok pesantren Tahfidzul Qur'an Al-Fanani terstrukturisasi dengan SK Rektor. Namun dari ketiga kyai pengasuh memiliki jabatan yang berbeda, sehingga walaupun memiliki kemampun yang sama tetapi memiliki jabatan yang berbeda maka akan kalah pengaruhnya atau beda pengaruhnya dengan kyai pengasuh yang memiliki jabatan tertinggi.

\section{Faktor situasi dan kondisi}

Di saat situasi yang tidak menentu dan kacau akan lebih efektif jika kyai pengasuh menerapkan karismatik. Jika organisasi pesantten ini sulit untuk maju maka perlu menerapkan kepemimpinan transformasional. Jika pesantren ini mencitrakan organisasinya maka kepemimpinan religiusitas atau spiritual diterapkan.

Menurut Imam Al-Ghazali dalam kitabnya Ihya Ulumuddin dijelaskan bahwa ada empat tugas pendidik/pengasuh dalam mendidik dan membina para santrinya, yaitu:

1. Menunjukkan kasih sayang kepada santri-santri dan menganggapnya seperti anak sendiri.

2. Mengikuti teladan pribadi Rasulullah.
3. Tidak menunda memberi nasehat dan ilmu yang diperlukan oleh para santrinya.

4. Menasehati santri-santri serta melarangnya dari akhlak tercela (Muchtar, 2008: 155).

Dari beberapa pernyataan di atas, kyai pengasuh berhasil dalam kepemimpinannya jika memiliki beberapa sifat diantaranya: Moril, disiplin, loyalitas, kecakapan dan sebagainya.

Sedangkan factor penghambat otoritas kyai pengasuh berdasarkan hasil observasi peneliti di pesantren adalah:

1. Kurangnya kerjasama antara kyai pengasuh yang satu dengan lainnya dalam menentukan kebijakan

2. Kurangnya komitmen untuk mengembangkan pesantren Tahfidzul Qur'an Al-Fanani Universitas Muhammadiyah Jember

3. Kedisplinan belum sepenuhnya ditegakkan baik oleh santri maupun oleh kyai pengasuh

4. Manajemen pengelolaan pesantren belum diterapkan sesuai fungsinya masing-masing

5. Para kyai pengasuh perlu memahami otoritas dalam ilmu manajemen, sehingga mampu menerapkan otoritas sesuai dengan fungsinya masingmasing.

Hal ini sesuai dengan teori yng terkait dengan tingkat otoritas manajerial tertinggi di puncak menurun sampai ke bawah dalam organisasi. Garis otoritas ini dekenal sebagai rantai komando (chain of command). Rantai komando ada jika seseorang menjadi bawahan dan yang lain. Rantai monsep komando, sebagaimana ditunjukkan oleh Buford, Jr. \& Bedelan (1988: 67), sangat terkait dengan dua prinsip manajemen popular yang lain yakni prinsip scalar dan prinsip kesatuan komando. 
Dampak Otoritas Kyai Pengasuh Terhadap Keberadaan Santri di Pondok Pesanstren Tahfidzul Qur'an Al-Fanani

Otoritas merupakan ciri dasar kehidupan di sekolah karena memberikan landasan bagi control sah para penyelenggara sekolah, guru, dan siswa. Sumber utama control adalah otoritas formal yang dilimpahkan kepada kantor atau jabatan, bukan pada orang tertentu yang menjalankan peran resmi tersebut (Merton, 1957). Ketika penyelenggara sekolah, guru, dan siswa bergabung dengan sebuah organisasi sekolah, menerima hubungan otoritas formal. Mereka setuju dalam batas-batas tertentu untuk mengikuti perintah yang dikeluarkan oleh para pegawai sekolah.

Beda halnya dengan pesantren, di mana kyai merupakan pemimpin dan manajer di lembaga. Semua otoritas dan kebijakan terletak pada kyai. Semua bawahan sami'na wa atho'na dengan keputusan kyai, tidak ada orang yang berani menentang terhadap kebijakan atau keputusan kyai. Ibarat pesantren adalah sebagai kerajaan kecil santri dan para guru harus tunduk dan patuh dengan aturan yg telah ditentukan. Namun kenyataan dari hasil observasi, pondok pondok pesantren ini hanya memiliki kyai pengasuh karena keberadaan pesantren yang ada di lingkungan Universitas Muhammadiyah Jember sehingga pengelola pesantren diserahkan pada pengasuh. Hal ini seprti yang diungkapkan oleh Rahman (2007:107) Walaupun pesantren banyak mengalami perubahan dalam system pendidikan, namun semuanya tidak lepas dari otoritas kyai sebagai pemilik dan pemangku kebijakan pesantren. Sehingga pada realitas kebanyakan pesantren menganut pola 'serba mono': mono manajemen dan mono-administrasi sehingga tidak ada delegasi kewenangan ke unit-unit kerja lain yang ada dalam organisasi.

Pola manajemen 'serba mono' dan serba informal tersebut memiliki korelasi yang signifikan sekali. Manajemen serba mono tersebut mengakibatkan manajemen serba informal. Kebiasaan pengelolaan pesantren 'serba mono' dengan kebijakan yang terpusat hanya pada kiai itu menyuburkan kekuasaannya dan tidak ada control sebagai penyeimbang sehingga mengakibatkan mekanisme formal tidak berlaku lagi. Hal ini juga berdampak pada jumlah santri.

Selain itu tidak meningkatnya jumlah santri di pondok pesantren Al-Fanani dikarenakan belum jelasnya citra pondok pesantren Tahfidz di kalangan mahasiswa Universitas Muhammadiyah Jember, selain itu ketidak jelasan pemangku otoritas di pesantren ini dikarenakan pesantren Al-Fanani di bawah lingkungan Universitas namun input yang ada beragam bukan hanya kalangan mahasiswa.

Sehingga menurut pengamatan peneliti, belum jelasnya tujuan pendirian pesantren Tahfidzul Qur'an Al-Fanani dengan indicator yang bisa dilihat adalah belum mempunyai visi dan misi yang jelas. Hal ini disebabkan oleh otoritas kyai yang kurang kerjasama dan belum mempunyai komitmen sepenuhnya untuk mengelola pesantren Tahfidz. Komunikasi antara pemimpin puncak, pengasuh dan bawahan perlu dibangun untuk mengembangkan pesantren ini.

Seperti apa yang diungkapkan oleh Wahjosumidjo dalam Model atau gambar di atas, tentang kepemimpinan dan motivasi (1993:65) dapat dijelaskan sebagai berikut:

a) Makin bergeser kekanan, makin meluas kebebasan bawahan, sehingga makin nyata bawahan dilibatkan dalam proses pengambian keputusan. Dan sebaliknya makin sempit otoritas pemimpin. Jadi, perilaku pemimpin 
berorientasi kepada bawahan atau disebut kepemimpinan yang bergaya demokratis.

b) Makin bergeser ke kiri, makin meluas otoritas pemimpin. Sehingga makin dibatasi kebebasan bawahan di dalam keterlibatan pengambilan keputusan. Jadi, perilaku pemimpin berorientasi kepada pemimpin atau dapat disebut pula kepemimpinan yang bergaya otoriter.

Berdasarkan teori di atas, jika para pengasuh berlaku demokratis, tidak adanya diskriminasi antara santri yang berstatus siswa dan mahasiswa serta dalam pegelolaan pesantren sesuai dengan fungsi-fungsi manajemen maka dari segi input-proses sampai pada out put menghasilkan kualitas sesuai dengan harapan masyarakat maka pesantren AlFanani terkenal di kalangan mahasiswa khususnya, wali mahasiswa dan masyarakat luas. Karena selama ini keberadaan pesantren ini hanya dikenal dikalangan tertentu tidak semua khalayak mengetahuinya.

Selain itu, jika kyai pengasuh lebih banyak menggunakan otoritas yang sah dan demokratis, harmonisasi antara kyai pengasuh terwujud, kedisiplinan pesantren ditegakkan maka pondok pesantren ini terus berkembang baik dari aspek jumlah santri yang bertambah, kehidupan pesantren yang nyaman dan sebagainya.

\section{KESIMPULAN}

Berdasarkan pada deskripsi dan merujuk rumusan maslah maka dapat disimpulkan :

Pertama, bentuk otoritas yang sering diterapkan di pondok pesantren Al-Fanai Universitas Muhammadiyah Jember lebih banyak menggunakan otoritas tradisional, sehingga walapun ada tiga kyai pengasuh namun keputusan lebih banyak pada ketua sebagai pemangku kebijakan pertama.
Sedangkan otoritas sah, hanya sekli-sekali diterapkan melihat kondisi pesantren

Kedua, Ada beberapa factor yang mendukung otoritas tersebut, salah satunya adalah dalam kegiatan tahfidz dan pembelajaran, otoritas sah yang diterakan oleh kyai pengasuh. Sedangkan factor penghambatnya adalah status santri yang tidak sama yaitu ada siswa dan mahasiswa latar belakangnya, kemudian penghambat selanjutnya adalah ketika kyai pengasuh tidak bisa membedakan kepentingan keluarga dan pesantren sehingga berdampak pada otoritas tradisonal yang diterapkan.

Ketiga, Dampak dari otoritas yang diterapkan kyai pengasuh adalah jumlah santri yang tidak ada kenaikan setiap tahunnya. Di samping itu sarana atau tempat yang kurang mencukupi jika ada peningkatan jumlah santri.

\section{DAFTAR RUJUKAN}

Arikunto, Suharsimi. Suhardjono. \& Supardi. (2006). Penelitian Tindakan Kelas. Jakarta: PT Bumi Angkasa.

Badan Penelitian dan Pengembangan Agama Departemen Agama RI. (2007). Modernisasi Pesantren. Jakarta: Badan Penelitian dan Pengembangan Agama Departemen Agama RI.

Bawani, Imam. (1993). Tradisionalisme dalam Pendidikan Islam, Studi Tentang Daya Tahan Pesantren Tradisional. Surabya: Al-Ikhlas.

Bahri Jamarah, Syaiful. (2002). Psikologi Belajar. Jakarta : Rineka Cipta.

Departemen Agama RI. (2003). Pola Pengembangan Pondok Pesantren. Jakarta : Depag RI..

Jauhari Muchtar, Heri. (2008). Fikih Pendidikan. Bandung : PT. Remaja Rosda Karya. 
Mastuhu. (1994) Dinamika Sistem

Pendidikan Pesantren.Jakarta:

INIS.

Mas'ud, Abdurrachman. (2002).

Dinamika Pesantren dan

Madrasah. Yogyakarta : Pustaka

Pelajar.

Mahfudh, Sahal. (1994). Nuansa Fiqih

Sosial. Yogyakarta: LKIS.

McShane, SL Von Glinow, MA. Organizational Behavior:

Enginering Realistic for the Work

Place Revolution. 2008. Mc

Graw hill. Irwin.

Moleong, Lexy J. 2002. Metodologi

Penelitian Kualitatif. Bandung:

Remaja Rosda Karya.

Rahman, Musthafa. (2002). "Menggugat Manajmen Pesantren", dalam Ismail SM., Nurul Huda dan Abdul Khaliq (eds), Dinamika Pesantren dan Madrasah, Yogyakarta: Kerjasama Fakultas Tarbiyah IAIN Walisongo semarang dengan Pustaka Pelajar.

Ramyulis. (2002). Ilmu Pendidikan Islam. Jakarta : Kalam Mulia.

Suprayogo, Imam. (1999). Reformasi Visi Pendidikan Islam. Malang: STAIN Press.

Wahjosumidjo. (1993). Kepemimpinan dan Motivasi. Jakarta: Ghalia Indonesia.

Yukl, Gary. (1994). Kepemimpinan dalam Organisasi; Leadrship in Organization. Alih Bahasa: Yusuf Udaya. Jakarta: Prenhallindo.

Ziemek, Mamfret. (1983). Pesantren dalam Perubahan Sosial. Jakarta: P3M. 
